\title{
Renal keratinising desquamative squamous metaplasia: all that hurts is not stone
}

\author{
Abhilash Koratala, ${ }^{1}$ Irfan Qadri, ${ }^{1}$ Vincent Bird, ${ }^{2}$ Rupam Ruchi ${ }^{1}$
}

'Department of Medicine/ Nephrology, University of Florida, Gainesville, Florida, USA ${ }^{2}$ Department of Urology, University of Florida, Gainesville, Florida, USA

\section{Correspondence to Dr Rupam Ruchi, Rupam. Ruchi@medicine.ufl.edu}

Accepted 12 June 2017

\section{DESCRIPTION}

A 66-year-old Caucasian man with history of hypertension, hyperlipidaemia and 16 pack-year smoking was referred to us for evaluation of recurrent right-sided flank pain and suspected nephrolithiasis. His first episode of pain was 2 years prior to presentation, which was recurrent. There was no associated haematuria, dysuria, fever, chills, urinary hesitancy or incontinence. There was no family history of stones. He underwent multiple ureteroscopies, which have shown glistening, soft, acellular debris in the upper ureter. Last ureteroscopy and pyeloscopy showed normal underlying mucosa, renal pelvis and calyces with no evidence of malignancy. Subsequent MRI also did not show any malignancy. The last available pathology showed minute fragments of acellular keratin debris. Interestingly, he never had imaging evidence of renal stone, although had mild hydronephrosis one time. CT urogram demonstrated an ill-defined filling defect in the anterior right renal pelvis measuring approximately $13 \times 3 \mathrm{~mm}$ in axial dimensions (figure 1). During the episodes of flank pain, he can feel 'something' sloughing off and traversing through the ureter. Excreted material is shown in figure 2. The presence of keratin in the ureteroscopic specimen indicated squamous metaplasia of the urothelial tract. We thus diagnosed him with renal keratinising desquamative squamous metaplasia (KDSM) and treated conservatively with adequate hydration and pain management.

KDSM is a condition in which the urothelium of the urinary tract is replaced with keratinised squamous epithelial cells. It can be confused with nephrolithiasis and/or neoplasia based on symptoms and appearance on imaging. Risk factors include chronic infection, stone disease or irritant exposure including smoking. ${ }^{1}$ There is no universally accepted treatment for this condition and was traditionally managed with radical measures such as nephroureterectomy. ${ }^{2}$ Current trend is towards conservative management, with endoscopic or open nephron-sparing procedures reserved for those with ureteral obstruction by desquamated keratinous material. KDSM has been associated with squamous cell carcinoma and transitional cell carcinoma without any proven causative relationship. Given the unlikely but possible transition to malignancy, it is prudent to monitor these patients with annual imaging.

Contributors AK: Evaluated the patient in the clinic and prepared the initial draft. IQ: Procured the images and helped in the evaluation of patient as well. VB: Urology attending who first
To cite: Koratala A, Qadri I Bird V, et al. BMJ Case Rep Published Online First: [please include Day Month Year]. doi:10.1136/bcr-2017220682
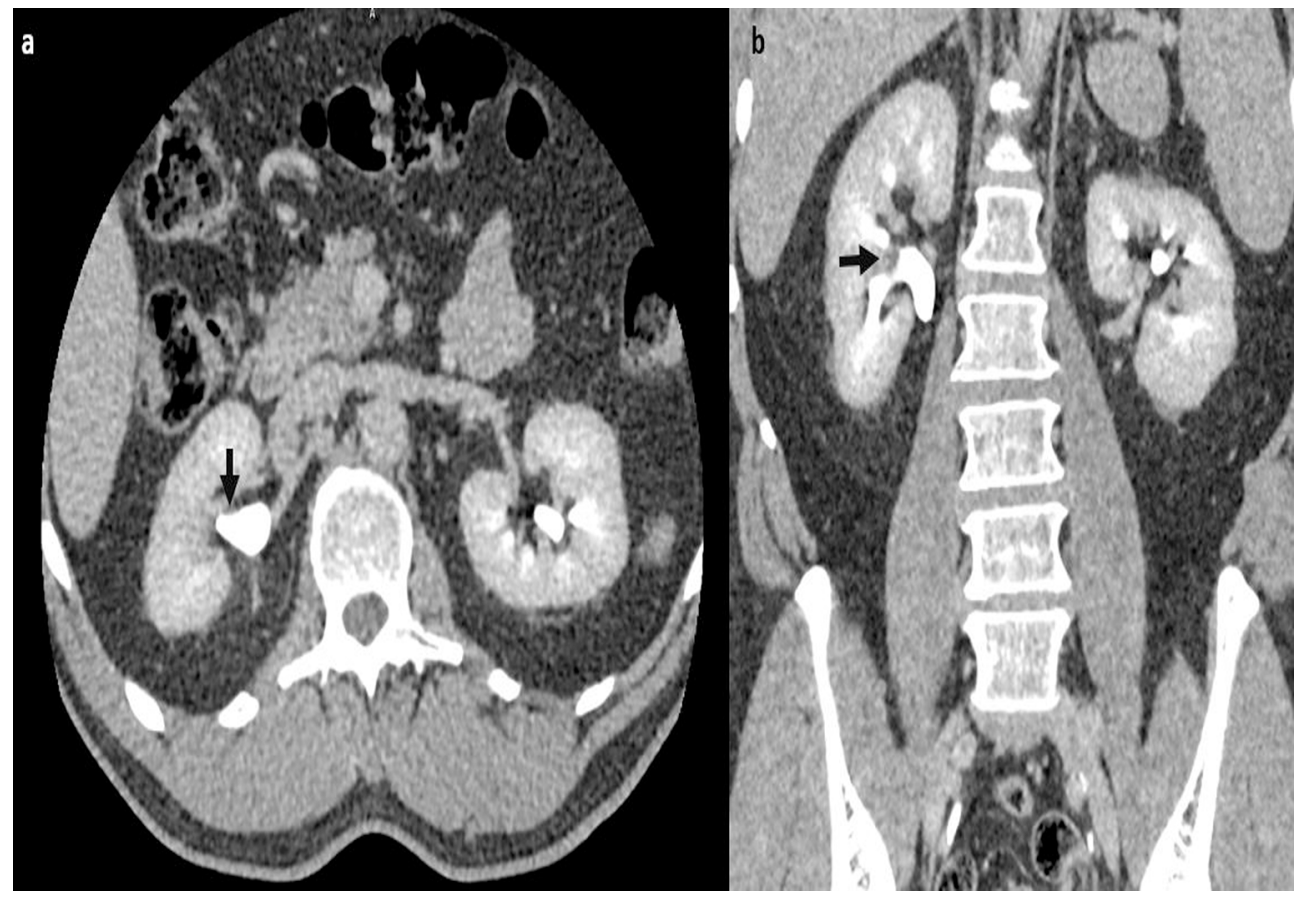

Figure 1 Transverse $(A)$ and coronal $(B)$ views of the CT urogram demonstrating filling defect in the right renal collecting system. 


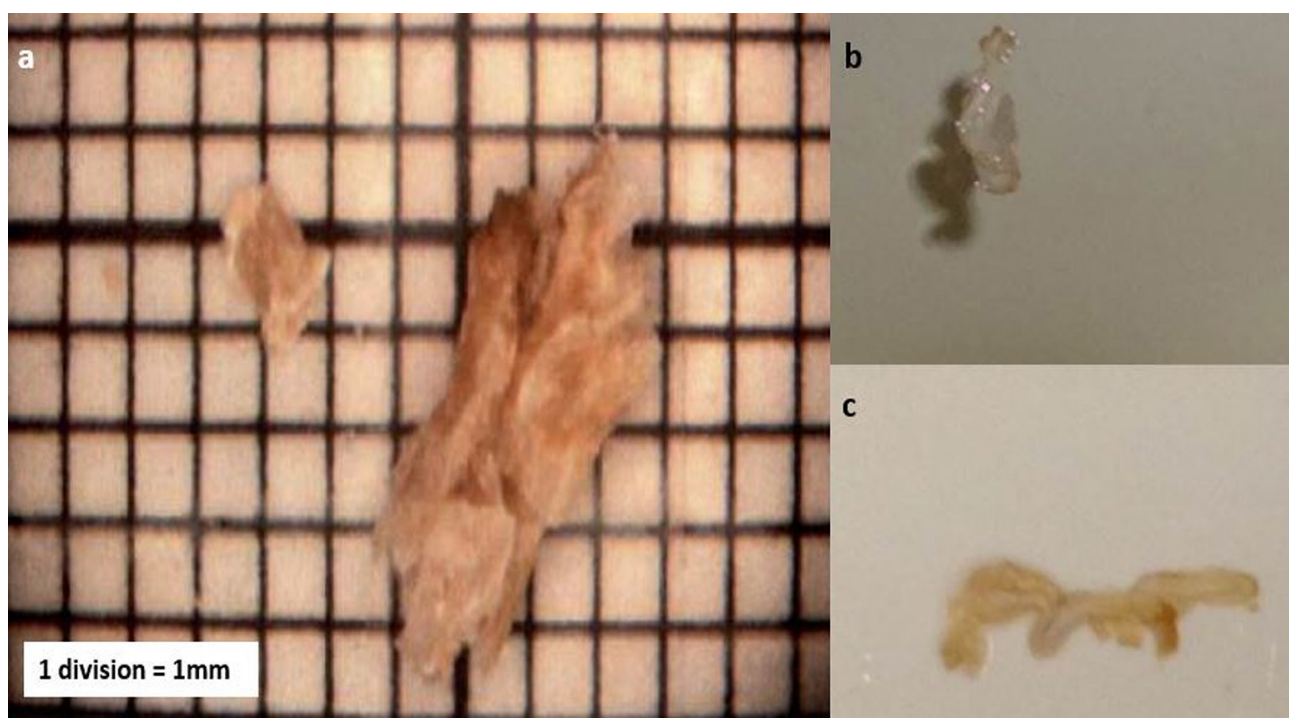

Copyright 2017 BMJ Publishing Group. All rights reserved. For permission to reuse any of this content visit http://group.bmj.com/group/rights-licensing/permissions.

BMJ Case Report Fellows may re-use this article for personal use and teaching without any further permission.

Become a Fellow of BMJ Case Reports today and you can:

- Submit as many cases as you like

- Enjoy fast sympathetic peer review and rapid publication of accepted articles

- Access all the published articles

- Re-use any of the published material for personal use and teaching without further permission

For information on Institutional Fellowships contact consortiasales@bmjgroup.com

Visit casereports.bmj.com for more articles like this and to become a Fellow 